Abstracta Iranica Abstracta Iranica

Revue bibliographique pour le domaine irano-aryen

Volume 24 | 2003

Comptes rendus des publications de 2001

\title{
Dāstān-hā-ye Čahāršanbe. Tehrān, Našr-e Ešāre, 1379/2000, 295 p. [Les récits du mercredi]
}

\section{Christophe Balaÿ}

\section{(2) OpenEdition}

1 Journals

\section{Édition électronique}

URL : http://journals.openedition.org/abstractairanica/34772

DOI : 10.4000/abstractairanica.34772

ISSN : 1961-960X

Éditeur :

CNRS (UMR 7528 Mondes iraniens et indiens), Éditions de l'IFRI

Édition imprimée

Date de publication : 15 mai 2003

ISSN : 0240-8910

Référence électronique

Christophe Balaÿ, «Dāstān-hā-ye Čahāršanbe. Tehrān, Našr-e Ešāre, 1379/2000, 295 p. [Les récits du mercredi] », Abstracta Iranica [En ligne], Volume 24 | 2003, document 266, mis en ligne le 05 janvier 2010, consulté le 25 septembre 2020. URL : http://journals.openedition.org/abstractairanica/34772 DOI : https://doi.org/10.4000/abstractairanica.34772

Ce document a été généré automatiquement le 25 septembre 2020.

Tous droits réservés 


\section{Dāstān-hāaye Čahāršanbe. Tehrān, Našr-e Ešāre, 1379/2000, 295 p. [Les récits du mercredi]}

\section{Christophe Balaÿ}

1 Après les « récits du jeudi » et les « récits du dimanche », voici ceux du mercredi, fruits de ces ateliers d'écriture, phénomène maintenant bien connu dans la vie littéraire iranienne post-révolutionnaire. Le recueil est constitué sur les mêmes principes que les deux précédents. Il contient 33 nouvelles assez brèves de vingt-deux auteurs différents plus une de Jamāl Mīr-șādeqī lui-même. On constatera ici encore que les femmes représentent les trois quarts des auteurs, phénomène désormais récurrent du monde de la nouvelle persane contemporaine.

\section{INDEX}

Thèmes : 11.1.2. Littérature persane moderne

\section{AUTEURS}

CHRISTOPHE BALA Ÿ

IFRI/INALCO - Téhéran/Paris 